\title{
JESUS THE KING, MERKABAH MYSTICISM AND THE GOSPEL OF JOHN
}

\author{
Jey J. Kanagaraj
}

\begin{abstract}
Summary
As King, the Johannine Jesus humbly reveals God's kingly glory, in sharp contrast to the world's expectations because he himself is, as the Son, one with the Father. This oneness in glory is plainly portrayed in John 12:41, where John interprets Isaiah's vision of the enthroned God as a vision of Christ's glory. A true vision of Jesus as King perceives him paradoxically as the Man in his lowliness, shame, suffering and crucifixion, and as the one who bears witness to the truth and exercises judgement. Such a presentation of Jesus' kingship indicates that John is addressing to some extent the Jews of his time who had great interest in Merkabah mysticism - the experience of seeing God on the throne in human-like form, after the pattern of Ezekiel 1, Isaiah 6, and Daniel 7. John testifies to what was seen and heard before the people, calling them to believe in Jesus, the Man and the King, and to see his glory enthroned supremely on the cross.
\end{abstract}

\section{Introduction}

The theme of kingship in Johannine Christology is a recognised feature of the Fourth Gospel. The Johannine depiction of Jesus as King has been explored recently by several scholars. W.A. Meeks, for example, argued in 1967 that in the Fourth Gospel, particularly in John 10 and 18:33-38a, Jesus' kingship is being redefined in terms of the mission of the prophet. ${ }^{1} \mathrm{He}$ understood kingship in John against the background of the mystical traditions centred on Moses, who, as some Jews from at least the second century B.C.E. believed, was crowned on Mt.

${ }^{1}$ W.A. Meeks, The Prophet-King: Moses Traditions and the Johannine Christology (Leiden: Brill, 1967) 67. 
Sinai as prophet and king. ${ }^{2} \mathrm{M}$. de Jonge developed this view further by saying that Jesus' kingship and his prophetic mission in John are both redefined in terms of the unique relationship between Son and Father. ${ }^{3}$ Nevertheless, it is often overlooked that the Johannine idea of kingship, which dominates the trial narrative (Jn. 18:28-19:16), links together several typically Johannine motifs; it, therefore, can hardly be dismissed by showing its link with Jesus' prophetic role or with his sonship alone. This article, in turn, seeks to examine afresh the nature of Jesus' kingship in John. Does John confine Jesus' kingship to his prophetic role alone? Or rather to his sonship? What are the other motifs and concepts which are used by John to describe Jesus as King? Why does he use them in relation to Jesus' kingship? A closer study of the Johannine passages concerned will not only lead us nearer to the solutions, but also to grasp the background against which Jesus' kingship can meaningfully be understood.

\section{The Nature of Jesus' Kingship}

\section{Nathanael's Confession}

Unlike in the Synoptic Gospels, in John the disciples recognise Jesus to be the Christ even during their first encounter with him; moreover, Jesus' messiahship is expressed in terms of his sonship and kingship at least by one disciple, Nathanael (Jn.

2Ibid., 205-15; cf. W.A. Meeks, 'Moses as God and King', in Religions in Antiquity: Essays in Memory of E.R. Goodenough, ed. J. Neusner (Leiden: Brill, 1968) 354-71. Meeks argues that John describes the mediatory function of Jesus in delivering to his disciples the 'words' and 'commandment' which God gave him (Jn. 1:17), similar to Moses' mediatory role in giving the Law, and that Jesus reveals God's Name (Jn. 17:6, 11-12) just as the Name YHWH was revealed to Moses (Ex. 3:13-14; 6:2-3) (Prophet-King, 286-91). He also states that just as Moses became God's שליה after his ascent and was sent to earth as prophet and king to reveal divine secrets, Jesus was sent by the Father as God's prophetic agent to reveal God's Name, to testify and judge the world (Jn. 17:6, 8, 11, 14; 3:11-21, 31-36) (Prophet-King, 301-307).

${ }^{3} \mathrm{M}$. de Jonge, Jesus: Stranger From Heaven and Son of God (Missoula: Scholars Press, 1977) 49-69; J. Ashton concedes this in his Understanding the Fourth Gospel (Oxford: Clarendon Press, 1991) 100 n. 76. 
1:49). When he first saw Jesus, Nathanael confessed him to be the Son of God and the King of Israel, though perhaps not realising the full significance of his kingship. That is why Jesus qualified these titles by another, Son of Man, with a promise that the disciples would see greater things than these (Jn. 1:50). What are these greater things? The Johannine Jesus himself answers in John 1:51: 'Truly, truly, I say to you, you will see heaven opened, and the angels of God ascending and descending upon the Son of man.'

G. Quispel argues that in John 1:51, a vision of the glorified Christ is promised, similar to the one mentioned in $12: 41$, and that this is indebted to the influence of an esoteric tradition, based on such theophanies as in Ezekiel 1 and Isaiah 6, which existed in Palestine in the first century. 4 This interpretation seems probable, since the notion of the heavens opening probably recalls Ezekiel 1:1. It is, however, improbable that the angels symbolise the Merkabah mystics who ascend and descend, as Quispel maintains. ${ }^{5}$ In view of the glory motif developed in John, Quispel is likely to be correct in suggesting that the vision of the Son of Man in 1:51 corresponds to the 'revelational form' of God (i.e., God's glory), described in Ezekiel 1:26 and Isaiah 6:1.6 This is confirmed by John's use of

${ }^{4}$ G. Quispel, 'Nathanael und der Menschensohn (Joh 1.51)', ZNW 47 (1956) 281-83. This esoteric tradition insisted on the experience of seeing a vision of the throne-chariot of God and of his glory (כבד) in human form, after the pattern of Ezekiel's vision in Ezk. 1 (cf. also Is. 6; Dn. 7), through which the mystic aimed to achieve a personal and intimate communion with God. See P.S. Alexander (ed.), Textual Sources for the Study of Judaism (Manchester: Manchester University Press, 1984) 26. The name 'Merkabah (or Throne-chariot) mysticism' was designated for such an experience as early as the mishnaic period (ca. 220 C.E.); see A.F. Segal, Paul the Convert (New Haven/London: Yale University Press, 1990) 39. That the early form of Merkabah mysticism was in practice in first-century Palestine is known from such writings as 4 QShirShabb, II Cor. 12, The Exagoge, Pseudo-Philo, The Similitudes of Enoch, 2 Enoch, 4 Ezra, The Apocalypse of Abraham, The Testament of Abraham, The Book of Revelation 4-5, and The Ascension of Isaiah vi-xi, and from the mystical tradition of the school of Yohanan ben Zakkai (1-80 C.E.).

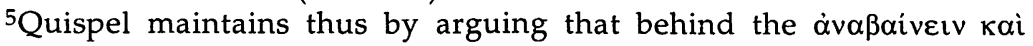

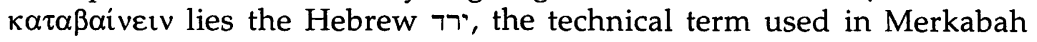
mysticism (Quispel, 'Menschensohn', 283).

6Ibid., 282. 
Genesis 28:12ff. to imply that the Son of Man, who represents Yahweh and the ladder of Jacob's vision, is the way to the Father ( $c f$. Jn. 14:6) as well as the very presence of God on earth (Jn. $1: 14,18 ; 14: 9,10)$. It is in Jesus, the Son of Man, that the real communion with God and communication between heaven and earth is possible, for he is the revelation of God's glory. Rowland rightly holds that the Son of Man in John 1:51 exhibits the very nature of God, his glory. ${ }^{7}$ Thus John 1:51 employs the language and ideas drawn from Merkabah mysticism that was prevalent in John's time. By presenting the Son of Man to be both the 'mystical way' to God and revelation of God's glory, John alludes to the heavenly journey undertaken by Merkabah mystics to see God.

The role of the ascending and descending angels in this revelatory act, then, can be no other than that of the angels who surround the chariot-throne of God, serving him and accentuating his glory ( $c f$. Dn. 7:10). Bühner argues that these angels symbolise the epiphany of the heavenly glory hidden in the earthly Jesus and, as ministers of God, their movements highlight the communication that is possible between heaven and earth in Jesus. ${ }^{8}$ What John 1:50-51 suggests is that there is now a possibility of seeing the heavenly glory and of having communion with God on the basis of ('̇ $\pi \dot{i}+$ accusative) what Jesus will accomplish by his death and exaltation. This experience, which is essentially the same as Merkabah mysticism, is for John 'seeing greater things' than simply seeing Jesus' supernatural knowledge. ${ }^{9}$ Thus John defines Jesus' kingship in terms of the Son of Man, highlighting his earthly

7See C. Rowland, 'John 1.51, Jewish Apocalyptic and Targumic Tradition', NTS 30 (1984) 500-504.

8J.-A. Bühner, Der Gesandte und sein Weg im 4. Evangelium (WUNT 2.2; Tübingen: J.C.B. Mohr [Siebeck], 1977) 391-92. The angels in the Hekhalot literature, a collection of the Jewish mystical writings composed probably in 200-700 C.E., are treated as figures who provide the link between the mysteries of heaven and the apprehension of the one who descends to the Merkabah.

9It should be noted that what a Merkabah mystic sees in heaven is God as King being seated on the throne. 
presence to reveal the Father's glory. ${ }^{10}$ It seems, then, that the primary issue in John 1:49-51 is not so much to recognise Jesus' kingly credentials as it is as the possibility of seeing Jesus the King in the right perspective.

\section{The King's Entry into Jerusalem}

The same idea of seeing the King of Israel with proper understanding dominates the event of Jesus' entry into Jerusalem (Jn. 12:12-19). In contrast to the public's perception of Jesus as a political deliverer of the Jewish national, John seems to insist that the glory of this King is exhibited in such humility that he made a young ass (óvópiov) to be his throne. This is clear from the placement of the event of finding an ass and riding on it after the crowd's acclamation of Jesus as 'King of Israel' (12:13-14). The use of Zechariah 9:9-10 in John 12:15 depicts the 'lowly' King to be the deliverer of Israel and the bringer of peace to the whole earth.11 The echoes of Zephaniah 3:14-17 and Isaiah 35:4 in John 12:13-15 describe Jesus as King who offers peace and salvation to his people and judgement to his enemies. By using the phrase 'Fear not...' in the place of Zechariah's 'Rejoice greatly...', John contrasts the Caesarrelated kingship that caused fear in Pilate (19:8) with the kingship of the one who sits on a donkey. For him, Jesus' authority as King is not indebted to the structures of power and manipulation that characterise this world (18:36).

Just as Nathanael's confession of Jesus' kingship was preceded by an act of 'seeing', so too the acclamation of the crowd implies 'seeing' before crying, 'Hosanna! Blessed is he who comes in the name of the Lord, even the King of Israel!' (12:13). Similarly, the idea of revealing God's glory seems to be common both to John 1:49-51 and to the entry-narrative. For John maintains that the glorification of Jesus through his death

${ }^{10} \mathrm{Cf}$. R. Bultmann, The Gospel of John (ET: Philadelphia: Westminster, 1971) 107.

${ }^{11}$ M.L. Appold's argument that the humility motif of Mt. 21:5 is 'deleted' by John is ill-founded (The Oneness Motif in the Fourth Gospel [WUNT 2.1; Tübingen: J.C.B. Mohr (Siebeck) 1976] 77 n. 1). Although John does not use the word 'humble' of Zc. 9:9, the expression 'sitting on an ass's colt' in his brief citation is sufficient to show the humble nature of Jesus' kingship. 
and resurrection was a necessary condition for understanding the royal significance of Jesus' entry into Jerusalem (12:16). This is reinforced by a reference to the sign of the raising of Lazarus from death (12:17-18), which indicates that the enthusiastic crowds should see a greater sign of Jesus' death and resurrection, in whom the glory of God's kingship can clearly be perceived. This means that the glory of Jesus as King, which was effectively revealed in his death and resurrection, is already present in his riding on the young ass. Therefore John found it appropriate to link the entry-narrative with Jesus' prediction of the glorification of the Son of Man by his death and resurrection ( $c f .12: 23-24,32-33$ ). By means of the entrynarrative, then, John seeks to lead the readers to understand the significance of Jesus' humiliating, but victorious, death in which is revealed his kingly glory. The idea of 'seeing' the different nature of Jesus' kingship from the world's expectations occurs again in John 6:14-15 and to this we now turn.

\section{Is Jesus, the King, also the Prophet?}

By treating the term 'the prophet' of John 6:14 and the term 'king' of 6:15 synonymously, Meeks argues that John 6:14-15 identifies Jesus to be prophet-king like Moses; according to Meeks, Jesus does not deny that he is a king, but denies only the timing and manner in which people tried to make him king. ${ }^{12}$ However, it is doubtful whether these two terms in John 6:14-15 convey the same idea, for in no other place, not even in the passion narrative where Jesus accepts the title 'king' for himself, does John identify the title 'prophet' with 'king'. In fact, 'prophet' is not at all used as a final title for Jesus and, as de Jonge points out, wherever this title occurs, eventually other titles such as the Christ, the Son of Man and the Son of God supersede it (see 4:19, 25-26; 6:14, 32-51; 7:40-43; 9:17, 35-38). ${ }^{13}$ It

\footnotetext{
12Meeks, Prophet-King, 87-91, 99.

${ }^{13}$ De Jonge, Stranger From Heaven, 50-66; J.D.G. Dunn, Christology in the Making (2nd edn.; London: SCM, 1989) 141, holds that John is moving beyond the more limiting confines of a prophet christology in view of his high Son of God christology. However, Jesus plays the role of a prophet in bearing witness to the eternal reality (18:37).
} 
is also likely that there is a break of thought between $6: 14$ and 6:15.14 If, after the sign, the people had really recognised Jesus to be the prophet promised by Moses ( $c f$. Dt. 18:15, 18), it is unthinkable how they could make a new demand to perform a sign (6:30-31). ${ }^{15}$ The statement in $6: 14$ is a confession not aroused by a deeper understanding of Jesus and his words, but by an excitement of having eaten their fill (6:26); it therefore indicates inadequate faith.

Those who saw Jesus to be 'the prophet' were prepared to seize him by force and make him king. Strachan argues that Jesus was in danger of being regarded as a kind of Theudas, who was said to be a prophet and who attempted to mount a political uprising in c. 43-44 C.E. (cf. Acts 5:36); in order to avoid such a messianic uprising, Jesus withdrew to the mountain. ${ }^{16}$ Does this mean that the Johannine Jesus accepted that he is a king but denied only the means by which he was about to be made king? If the notion of the messianic claimants was in the evangelist's mind in 6:14-15, as is probable in view of the use of the term 'the one who is to come', then it is likely that, in this context, Jesus rejected the very title 'king'. Because he is already a king ( $c f .18: 37)$, there was no necessity for any one to make him king. ${ }^{17}$ In view of the fact that in other places Jesus accepts that he is king $(1: 49 ; 12: 13-15 ; 18: 36-37)$, the term 'king' in 6:15 likely portrays the lowly nature of Jesus' kingship, which is unacceptable to the world.

\section{Summary}

Clearly John portrays Jesus to be king, who reveals his kingly glory in a humble manner, seated on a donkey; for John, such a kingship can fully be grasped only in the light of Jesus' death and resurrection. As his kingship is not described in terms of the prophet like Moses, we can scarcely understand the kingly

\footnotetext{
${ }^{14} \mathrm{Cf}$. Appold, Oneness Motif, 77.

${ }^{15}$ See R. Schnackenburg, The Gospel According to St. John, vol. 2 (ET; New York: Crossroad, 1990) 18-19.

16R.H. Strachan, The Fourth Gospel (3rd edn.; London: SCM, 1946) 180. See also C.H. Dodd, Historical Tradition in the Fourth Gospel (Cambridge: CUP, 1965) 214; G.R. Beasley-Murray, John, (WBC 36; Dallas: Word, 1987) 88-89. 17De Jonge, Stranger From Heaven, 58.
} 
glory of Jesus against the background of Moses tradition, as Meeks has postulated. Moreover, Moses made a mystical ascent to Sinai where he was made king, whereas the Johannine Jesus is king by the very fact that he has continual communion with the Father. The idea of the revelation of Jesus' kingly glory makes Merkabah mysticism the most likely background for understanding the king-motif in John. It should be borne in mind, however, that in contrast to the mystical visions, the Johannine Jesus is to be seen as king in his lowliness, enthroned on a humble animal and supremely on the cross. How can one see Jesus' kingly glory on the cross? To answer this question we will examine the idea of kingship, pictured in the Johannine passion narrative and this will shed light on the importance of the relationship that exists between Jesus' kingship and the glory-motif in John's Gospel.

\section{The Revealed Glory in Jesus' Kingship}

\section{Jesus' Kingship is God's Kingship}

The title 'King' plays a key role in the Johannine trial narrative. ${ }^{18} \mathrm{C}$. Panackel states that the revelation of Jesus' Kingship is 'the only unequivocal and direct self-revelation of Jesus' in the trial-narrative of John. ${ }^{19}$ Like the Synoptists, John also begins the dialogue between Pilate and Jesus with a reference to Jesus' kingship (18:33), defining it initially in negative form in 18:36: 'My kingdom is not of this world' (̇ंк

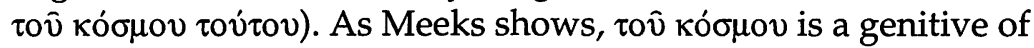
origin 20 the implication being that Jesus' kingship derives not from the world but from God (cf. the similar construction in $8: 23)$. Since Jesus' kingship originates precisely from the place

\footnotetext{
18See D. Hill, "My Kingdom is not of this World" (John 18:36): Conflict and Christian Existence in the World According to the Fourth Gospel', IBS 9 (1987) 55, who holds that Christ's kingship, culminating in his enthronement on the cross, is the thread which binds together the entire Passion story, particularly the trial-narrative.

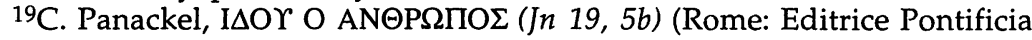
Università Gregoriana, 1988) 334.

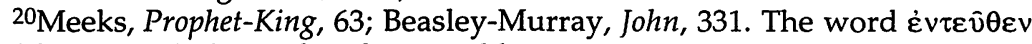
('from here') also makes this possible.
} 
of his own origin, that is, from God (cf. $3: 31 ; 8: 42)$, his kingly glory is the same as God's kingly glory. Therefore there is no need for the kingdom to be established, for example, by using military strategies, as earthly kingdoms are established ( $c f$. 18:36b). This idea possibly implies that the kingly glory of God, with which Merkabah mysticism is concerned, has become visible in Jesus. Further investigation confirms this.

By showing the compositional parallels between the kingdom of God in 3:3-5 and that of Jesus in 18:36, Hengel justly argues that the kingly rule of God, which is the subject of Jesus' dialogue with Nicodemus, is identical with the kingly rule of Christ, which is emphasised in Jesus' encounter with Pilate, and that in the place of the synoptic kingdom of God there emerges in John the kingdom of his Son.21 Schnackenburg maintains that John's description of the kingdom of Jesus does not indicate the heavenly realm to be the kingdom of God.22 But Chilton has convincingly shown that in the first century, particularly in the school of Yohanan ben Zakkai, the kingdom of God was conceived more as the self-revelation of God. ${ }^{23} \mathrm{He}$ argues that Jesus and Yohanan shared a common kingdom vocabulary, preserved in the New Testament and the Targums, and that by the term 'Kingdom of God' Jesus meant that God is active among us. ${ }^{24}$ We have enough evidence to show that Yohanan and his school were practising Merkabah mysticism in which the kingship of God played a key role. ${ }^{25}$ It is plausible,

${ }^{21} \mathrm{M}$. Hengel, 'Reich Christi, Reich Gottes und Weltreich im Johannesevangelium', in Königsherrschaft Gottes und himmlischer Kult im Judentum, Urchristentum und in der hellenischen Welt, M. Hengel and A.M. Schwemer (eds.) (Tübingen: J.C.B. Mohr [Siebeck], 1991) 176-79.

22Schnackenburg, John, vol. 3, 249.

23B.D. Chilton, 'Regnum Dei Deus Est', in his Targumic Approaches to the Gospels (New York/London: Lanham, 1986) 99-107, especially 101-105.

${ }^{24}$ Ibid., 101, 105.

${ }^{25}$ The primary evidence for the possibility of mystical practice in Yohanan's school is the Merkabah exposition delivered by one of Yohanan's disciples, Eleazar ben 'Arakh and recorded in four different versions: Mekhilta de R. Simeon ben Yohai, t. Hag. ii.1, y. Hag. ii.1, and b. Hag. 14b. The lack of literary evidence for Yohanan's practice in the first century C.E. is explained by the fact that esoteric speculation was kept secret; see J. Neusner, A Life of Yohanan ben Zakkai (Leiden: Brill, 1970) 137; A. Biram ('Ma'aseh Bereshit; Ma'aseh Merkabah', Jewish Encyclopedia 8 
then, that John could have used the same mystical notion in his presentation of the kingdom of Jesus as embodying the kingdom of God in order to convince the Jews who had great interest in Merkabah mysticism that God had revealed himself in his Son as King.

The unity between the kingship of the Father and that of the Son is clearly known in John's daring interpretation of Isaiah's vision of the enthroned God as a vision of Christ's glory (12:41). God exercises his kingship in the world by sending his Son into it (3:16; 1 Jn. 4:9-10).26 The kingship of Christ is grounded in the pre-existence of the Son with the Father in the heavenly realm. This is evident from two expressions in 18:37: 'For this I was born' and 'for this I have come', where 'for this' refers back to the kingdom motif of 18:36-37. It is in the earthly life of Jesus that one can see him to be king.

Jesus' kingship is further qualified by 'to bear witness to the truth' (18:37). According to Meeks, this statement shows that Jesus' kingship consists in his mission of testifying to the truth. 27 'Truth' in John denotes 'the eternal reality which is beyond and above the phenomena of the world' and, in particular, the eternal kingdom of God, the origin of all human authority (19:11). ${ }^{28}$ It is precisely this eternal reality that presents itself to humankind in incarnate form either for salvation or for judgement, depending upon the response one gives to the truth (cf. 3:31-36; see 8:14, 16, where 'testimony' and 'judgement' are paralleled).

The idea of bearing witness to the truth is followed by the words, 'Every one who is of the truth hears my voice' (18:37b), referring to those who will obey the words spoken by

[1907] 236) suggests that Yohanan refused to discuss the secret doctrine even in the presence of a single person, although he was its founder. For further defence, see my Ph.D. thesis, 'Mysticism' in the Gospel of John: An Inquiry into the Background of John in Jewish Mysticism (Durham University, 1995) 121-28.

26See Hengel, 'Reich Christi', 169.

27Meeks, Prophet-King, 65.

${ }^{28}$ C.K. Barrett, The Gospel According to St. John (2nd edn.; Philadelphia: Westminster Press, 1978) 537; cf. C.H. Dodd, The Interpretation of the Fourth Gospel (Cambridge: Cambridge University, 1958) 176. 
the king. That is, the one who has seen Jesus to be king is 'of the truth' and only that person can obey the eternal reality that is revealed through the witness borne by the king. But Pilate, being the representative of the earthly kingdom is wholly unable to perceive the kingship of Jesus and hence does not grasp what the truth is.

Suggesting a parallel here with the Shepherd-Sheep imagery in which the sheep hear the shepherd's voice (10:3), and also with the prophet like Moses whom the people of Israel should heed (Dt. 18:15), Meeks argues that the kingship of Jesus, the Good Shepherd, is redefined in John in terms of the mission of 'the prophet like Moses' who is referred to in Deuteronomy 18:15.29 Undoubtedly Shepherd and King are closely related terms ( $c f$. Ezk. 37:24; Ze. 11:6), but the idea of hearing his voice cannot be confined to the Mosaic prophet alone. The phrase 'hear my voice' should be interpreted not in isolation, but in its context of the revelation of Jesus' kingship and of his witness to the eternal reality. Viewed thus, the closest parallel to the idea of hearing his voice lies in Merkabah mystical visions. When Isaiah saw the Lord in his kingly glory,

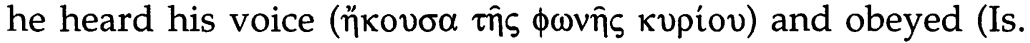
6:8). Similarly, Ezekiel, in his chariot vision, heard the voice of

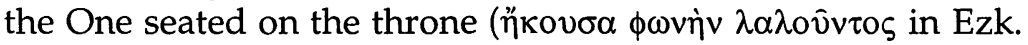

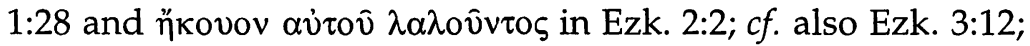
10:5; 43:6; 1 En. 15:1; Ap. Ab. 18:14; 19:1; Rev. 1:10,12-16,19-20).

The Merkabah tradition also refers to the witness borne to the people by the one who saw God to be King; this witness carried the function of judgement that offered salvation and condemnation, depending upon the hearers' response. ${ }^{30}$ No doubt, the act of witnessing to the divine secrets is found in the mystical tradition centred on Moses. ${ }^{31}$ But the idea of kingship based on Father-Son relationship and that of king-judge are not so explicit in Moses-centred mysticism. There is a possibility that Moses' vision in the Exagôgê could have been described by

\footnotetext{
${ }^{29}$ Prophet-King, 66-67.
}

${ }^{30}$ Apart from the throne-visions of Ezk. 1, Is. 6, and Dn. 7, see 2 En. 33ff.; 2 Esdr. 15-16.

31See Meeks, Prophet-King, 301-307. 
using the literary form of a Merkabah vision. ${ }^{22}$ Therefore it is probable that John, in his description of Jesus' kingship, used the Merkabah mystical notion mainly to convey the message to his fellow-Jews that the same God, who is claimed by the mystics to have appeared on the throne as King, has now been revealed on earth to be King in the incarnate life of his Son. Just as the kingly appearance of God involves judgement in terms either of salvation or of destruction, so too God's kingship revealed in Jesus involves judgement. John, thus, was not hesitant to identify the kingship of Jesus with that of God.

If the kingship of Jesus is one with that of God, one can ask: Where is the throne on which Jesus appeared? Is Jesus described in John to be the king surrounded by the angels? These issues are considered in the next section.

\section{Jesus the King in his Paradoxical Exaltation}

Meeks maintains that John declares Jesus to be king in his 'paradoxical exaltation' throughout the trial proceedings. For example, unlike Matthew and Mark, John records in the early part of the trial itself the mocking of Jesus by the soldiers as 'King of the Jews' (19:1-3). ${ }^{33}$ This mockery occurs as the ironic investiture and coronation of Jesus, 34 for after this Jesus is presented before the Jews with a purple robe and a crown of thorns by two parallel proclamations: 'Behold the Man' (19:5) and 'Behold your King' (19:14). These proclamations have revelatory connotation, for they emphasise dramatically the experience of 'seeing' Jesus to be the Man ( $c f .4: 29 ; 7: 46 ; 8: 40$ ) and at the same time as he is recognised to be the King of the Jews. Painter shows that prior to Jesus' death, the nature of his kingship was being revealed in the Son of Man sayings and that after chap. 13, Jesus is referred to as king twelve times without using the title Son of Man. ${ }^{35}$ If so, the parallel use of 'Man' and

\footnotetext{
32See P.W. Van der Horst, 'Moses' Throne Vision in Ezekiel the Dramatist', JJS 34 (1983) 21-29.

33Meeks, Prophet-King, 69.

34See F.J. Moloney, The Johannine Son of Man (Rome: Las, 1978) 204-205.

35J. Painter, 'The Enigmatic Johannine Son of Man', in F. van Segbroeck et al. (eds.), The Four Gospels 1992, vol. 3 (Leuven: University Press, 1992) 1881.
} 
'King' can ironically indicate that Jesus is King as the Son of Man rather than as the messianic eschatological king, as Meeks suggests. ${ }^{36}$ Thus the ecce homo evokes for perceptive readers the heavenly vision promised in 1:51 which, as we have seen above, contains the mystical idea of seeing God's glory in the Son of Man.37

However, the Jews were unable to perceive this paradoxical element embodied in the ecce homo, and cried out on both occasions the same slogan: 'Crucify him' $(19: 6,15)$. The revelation of the King as the Man in his blood-stained appearance confirms our earlier observation that the kingly glory of Jesus is to be seen in the suffering and death of the Son of Man (cf. 18:32). The kingship and the glorification of Jesus, thus, are skilfully interwoven by John in these two ironic proclamations $(19: 5,14)$.

The revelation of Jesus' glory equally as Man and King recalls Merkabah mystical visions in which God, the King, was thought to have revealed his glory in human-like form. But John probably interprets this mystical idea to proclaim that the kingly glory of God has now appeared in time and space in Jesus, who was lifted up on the cross in utter shame and humiliation. Jesus, for John, displays his kingly glory not only by being enthroned on the cross, but also by being surrounded by hostile forces, the Jews who eventually got him crucified, rather than by the angels, as in Merkabah mystical visions. That the cross is the throne from which the divine king reigns is supremely demonstrated by the irrevocable title the King of the Jews', written on the cross possibly as a mark of Pilate's final verdict (19:19-22). Therefore Meeks is right in calling 'the Man' and 'the King' 'the throne Names'.38

36Meeks (Prophet-King, 70-72) uses Zc. 6:12 (LXX) and Nu. 24:17 (LXX) in support of this conclusion. However, Barrett (John, 541) doubts a direct reference to Zc. 6:12.

37Moloney (Son of Man, 205-206) argues that the promise of $1: 51 ; 3: 14 ; 6: 27$, 53 and 8:28 becomes real in the ecce homo scene. Cf. Panackel, O

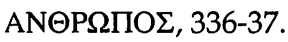

38Meeks, Prophet-King, 69-78. Cf. Col. 2:15; Justin, Apology I.41; Dialogue 73:1; Epistle of Barnabas 8:5 for the idea that Jesus rules from the cross. 
Our earlier observation that for John the kingship of Jesus is the same as the kingship of God is reinforced by the title 'Son of God' used in the trial narrative. Not able to accept the Man (deprived of worldly power) as their King, the Jews attempted to divert the focus to Jesus' claim that he is the Son of God, i.e., the one equal to God, a claim which deserves the death penalty $(19: 7 ; c f .5: 18) .{ }^{39}$ However, the earlier Johannine trial stresses repeatedly the claim 'King' $(19: 12,14,15,19$, 21$22)$, thereby giving a hint once more that Jesus is King who has a filial relation and equality with God (cf. 1:49 with 1:14, 18). That Jesus' kingship is based on his intimate unity with God is envisaged by the parallelism between the phrase 'he made himself the Son of God' of 19:7 and the phrase 'the one who makes himself a king' of 19:12. The same idea is implied in Pilate's increased fear of Jesus' divine sonship and in his question, 'Where are you from?' (19:9), expecting an answer, 'from above' (cf. 19:11).40

For John, then, if God is King, Jesus also is King and it is impossible to see God in his kingly glory without seeing his Son also in his kingly glory, ${ }^{41}$ which, in contrast to human expectations, is manifested in the Son's suffering and death, an offence to 'the Jews'. That is, the kingship of Jesus, which paradoxically holds together the concept of the Son of Man and

${ }^{39}$ The anarthrous viòs $\theta \varepsilon 0 \hat{v}$ does not make Jesus less than equal with God. The omission may indicate either the familiarity of the title (so J.H. Bernard, A Critical and Exegetical Commentary on the Gospel According to St. John, vol. 2 [Edinburgh: T. \& T. Clark, 1949] 618) or its qualitative use (so Barrett, John, 542).

${ }^{40}$ The word $\mu \hat{\alpha} \lambda \lambda$ ov here means 'even more, now more than ever' (see $W$. Bauer, W.F. Arndt, and F.W. Gingrich, A Greek-English Lexicon of the New Testament and Other Early Christian Literature [2nd edn.; Chicago: University of Chicago, 1979] 489) and not 'instead', as D. Rensberger suggests ('The Politics of John: The Trial of Jesus in the Fourth Gospel', $J B L 103$ [1984] 405). The meaning 'instead' is possible only when $\mu \hat{\alpha} \lambda \lambda$ ov is followed by a negative ( $c f$. BAG, s.v. 3a). Pilate's previous fear at Jesus' statement about his kingship is implied in his ignoring the statement by asking 'What is truth?'; see Schnackenburg, John, 3.260.

${ }^{41}$ Hengel ('Reich Christi', 166, 172, 179) argues that God's task of restoring his creation was precisely undertaken by Jesus as the enthroned king on the cross; and that this exhibits the unity that exists between the kingship of Jesus and that of the Father. 
that of the Son of God, was hard for the Jews to grasp, partly because of their association with the mystical practice that focused purely on the heavenly glory of the King. The equality between Jesus' kingship and God's kingship based on the Father-Son relationship is precisely missing in the mystical tradition of Moses.

\section{Jesus, the King, is Judge}

John portrays the crucified King as the bearer of judgement to the world ( $c f .12: 31 ; 16: 11$ ), for the King's testimony to the truth exposes the moral condition of the people and judges them either for salvation or for condemnation, depending upon their response to the truth $(18: 37 ; 3: 19-21)$. Ashton observes that judgement is the most important theological motif in the trial sequence, for by bringing Jesus to trial and sentencing him to death, the Jews were actually passing judgement on themselves. 42

Not only the verb 'to testify' (18:37), but also 'sat down' ( $\dot{\varepsilon} \kappa \dot{\alpha} \theta \sigma \varepsilon v ; 19: 13)$ reveals the crucified King to be judge. Scholars have pointed out that $\dot{\varepsilon} \kappa \alpha \dot{\theta} \theta \varepsilon v$ can be understood either transitively or intransitively. If taken intransitively, the sense is that it was Pilate who sat upon the judgement seat $(\beta \hat{\eta} \mu \alpha)$; but if treated transitively, then the sense is that Pilate made Jesus to sit on the judgement seat; his motive in doing so would have been to persuade the Jews to acknowledge Jesus to be their King-Judge, thereby of testing their loyalty to Caesar. Though good case can be made in favour of both interpretations, 43 the arguments favouring the latter transitive sense seem stronger, as shown below.

42Ashton, Understanding the Fourth Gospel, 226-29.

${ }^{43}$ In favour of intransitive sense, see Ashton, Understanding the Fourth Gospel, 228 n. 41; Bultmann, John, 664 n. 2; Beasley-Murray, John, 341. Those who argue for the transitive sense include Meeks, Prophet-King, 7376; R.E. Brown, The Gospel According to John (xiii - xxi) (New York: Doubleday, 1970) 880-81; E. Haenchen, John, vol. 2 (ET: Philadelphia: Fortress, 1984) 183; T.L. Brodie, The Gospel According to John (Oxford: Oxford University, 1993) 538-39. Barrett (John, 544) thinks that in the light of John's tendency to play on words of double meaning, both meanings are implied. 
(i) Although in the Matthean parallel it is Pilate who is seated on the judgement seat (Mt. 27:19), John presents this

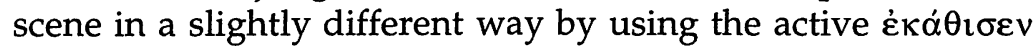
instead of the middle $\kappa \alpha \theta \eta \mu \varepsilon ́ v o \varsigma$, and by closely linking it with

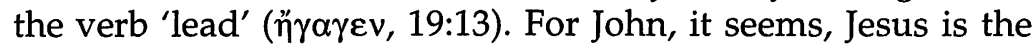
object of the verb 'sat down'. 44

(ii) The transitive sense gives a good sequence to Pilate's first declaration 'Behold the Man', for at first Pilate introduces Jesus with his crown of thorns and purple robe (19:5), but when he knows that Jesus claimed to be Son of God, he becomes more fearful and seeks to release him (19:7-12). Such a reverence would have led Pilate to make a final attempt to show Jesus to be the King of the Jews and this time by making him sit on the throne of judgement. Thus John gives a dramatic force to Pilate's words 'Behold your King' (19:14).45

(iii) The transitive sense seems relevant to the context in which the identification of Jesus as King becomes a crucial issue and the Roman ruler firmly accepts Jesus to be the King of the Jews (cf. 19:12, 14, 15, 19, 21-22).

(iv) The cry of the Jews by the words ô $\rho$ ov $\alpha$ ôpov (usually translated 'Away with him, away with him'), in addition to 'crucify him' in 19:15, stresses the idea of 'lifting up' obviously from the throne of judgement.

It is clear that John uses the traditional materials with the christological purpose of showing that Jesus is King, who brings salvation and judgement to humans by bearing witness to the heavenly reality. The idea that the Son has been granted authority to judge because he is Son of Man has already been mentioned by John in 5:27, so there should be little surprise when the same idea is applied to the crucified Man and King. This echoes the Merkabah mystical visions, Daniel 7 in particular, which portray the offer of salvation and judgement by the human-like figure seated on the throne. John brings such a vision to earth, proclaiming that God's kingship is indeed revealed in Jesus of Nazareth and that his glory lies in his utter

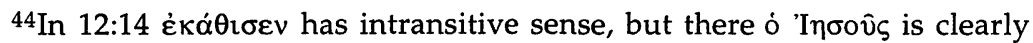

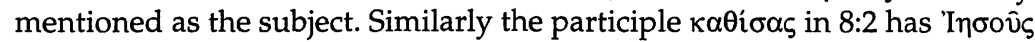
as the subject $(8: 1)$.

${ }^{45} \mathrm{Cf}$. Barrett, John, 544 . 
humiliation and death. The arguments posed by Dodd, Rensberger and Hengel for the political situation of the late first century for understanding the Johannine trial narrative ${ }^{46}$ do not adequately explain the recurring key concepts such as: the revelation of Jesus' glory as King; the oneness of the kingship of God and that of Jesus; and the King's mission of bearing witness to the truth, thereby bringing salvation and condemnation. Therefore along with the political context, the religio-historical context of the late first century should also be taken into account. Viewed thus, the mystical speculation centred on Ezekiel's chariot emerges as the more relevant context to explain the polemical tendency of John, for it is the Merkabah tradition which aroused an interest in the minds of some Jews to see God in his kingly glory, to bear witness to what they had seen and to ascribe the task of judgement to a human figure seated on the throne.

\section{Conclusion}

Our study shows that John describes Jesus to be King in the sense that he reveals God as King. Even from the early part of John's Gospel the kingship of Jesus is closely linked with his sonship. However, the kingship of God that is revealed in his Son can fully be appreciated only in his role as the Son of Man, who, for John, is not only the means of communication between heaven and earth, but also the place where one can see the very nature of God, his glory.

The idea of 'seeing' the glory of the King in Jesus' lowliness, death and resurrection is implied in the Johannine title 'Son of Man' and foreshadowed in the entry narrative of John. It is the sign of Jesus' death and resurrection which will bring the glory of his kingship in its full splendour (cf. 12:16). John 6:14-15, which juxtaposes the two terms, Prophet and King, does not seem to show that Jesus' kingship should primarily be understood against the background of the mystical tradition based on Moses, the prophet-king, as Meeks has

46Dodd, Tradition, 112-20; Rensberger, 'The Politics of John', 395-411; Hengel, 'Reich Christi', 166-67, 170-84. 
advocated. But it reinforces our thesis that the kingship of Jesus is to be seen not in his pomp and worldly glory, but in his lowliness. Thus we see that the king-motif in John is inevitably linked with the notion of 'seeing' and also with the title 'Son of Man' in whose glorification God's glory was revealed (cf. 13:3132). This suggests that the early form of Merkabah mysticism, which focused on seeing God's kingly glory in human-like form, provides a better background against which John's kingmotif should be understood. In contrast to the mystical visions, however, John seems to present Jesus as King in his lowliness, enthroned on the cross.

The Johannine Passion narrative, in which the title 'King' plays a key role, brings the mystical background into sharp focus. While describing the suffering and death of Jesus, John portrays Jesus' kingly glory as based on his intimate unity with God and, hence, as the revelation of God's kingly glory. For Jesus, as King, bears witness to the eternal reality ('truth'), exercises judgement, and exhibits his status as the Son of God. This three-fold character of Jesus' kingship exactly fits in the Jewish mystical notion of the first century; focusing on Ezekiel's Merkabah, it speaks of the human figure, implicitly the one who has been one with God, revealing God's glory and rendering judgement. In Merkabah visions, the visionary becomes a witness for what he had seen and heard in heaven, whereas in John the visionary, who bears witness as King, himself is God's self-manifestation.

From all this, it seems likely that John has presented this aspect of his christological portrait for the benefit of those Jews who had great interest in Merkabah mysticism; with them in view, John proclaimed that God had revealed himself as King in his Son and that, in contrast to the expectation of the world, Jesus manifested God's glory on the cross, surrounded by hostile forces. If so, it seems that the Jewish 'Throne-Chariot mysticism' is reinterpreted by John as 'Cross mysticism'. It is impossible, then, to understand the Johannine King-motif without linking it with the ideas of seeing and witnessing, the title Son of Man, the glory-motif, the notion of judgement, and with Jesus' death and resurrection. 